\title{
THE FAÇADE WALL: A FOCUS ON THE GREEN ARCHITECTURE OF LAURIE BAKER'S HOUSES
}

\author{
ANJALI SADANAND ${ }^{1, *}$, R.V. NAGARAJAN ${ }^{1} \&$ MONSINGH DEVADAS $^{2,} \dagger$ \\ ${ }^{1}$ Hindustan Institute of Technology and Science, India. \\ ${ }^{2}$ Measi Academy of Architecture, India.
}

\begin{abstract}
This paper is an attempt to illustrate 'green' strategies Laurie Baker uses, in particular with respect to passive design principles as applied to houses. Green architecture is holistic and socially sensitive as it, in addition to being environmentally conscious, addresses the well-being of its users. This paper will focus on the method of harvesting 'green' ideals with respect to the architecture of the façade wall in Laurie Baker's houses. Three houses designed by Baker in the 1990s in Trivandrum, Kerala will be studied. The discussion will show that Baker's façade design strategies represent innovative solutions for facade designs built on low technology with derivations from the local vernacular in a contemporary architectural language. In the larger context of architecture of sustainability and green architecture, Baker's approach, it will be shown, is essentially humanist and presents a way forward to establishing identity through place and an understanding of culture. In a digital era, which challenges identity and encourages notions of connectivity in a global sense, Baker's architecture, it will be proposed, promotes green principles in making significant the value of the local and in the credence it gives to the end user and the craftsman in a singularly unique architectural language.

Keywords: brick, façade wall, green architecture, passive design, sustainability.
\end{abstract}

\section{INTRODUCTION}

\subsection{Definitions}

'Green design is place-sensitive' [1]. 'Green-building concepts extend beyond the walls of buildings and include site planning, community and land-use planning issues as well' [2]. 'The processes of constructing and operating a building affect the environment' [1]. In the larger context, the environmental effect has global impacts and can affect climate change. 'A green building should integrate consideration of environmental impact and occupant health and comfort' [3]. A green building is not looked at as static solution but designed with green principles from its inception through its lifetime and to its demolition. The process becomes significant. 'A sustainable building refers to both the structure and a process that is more environmentally responsible during the entire life cycle of a building' [3].

\subsection{Principles of green building design [4]}

The principles of green design are based on the following five major elements:

1. Sustainable site design,

2. Water conservation and quality,

\footnotetext{
* Anjali Sadanand, Professor Measi Academy of Architecture

$\dagger$ Dr. Monsingh Devadas, Principal, Measi Academy of Architecture
} 
3. Energy and environment,

4. Indoor environmental quality and

5. Conservation of materials and resources.

\subsection{Relationship of architectural design to well-being}

In A Green Vitruvius, the authors look at Vitruvian concepts of firmness, commodity and delight with respect to green architecture. They comment 'at the scale of the building, too, quality of architecture involves suitability, firmness and durability, and delight' [1]. A holistic view is thus projected. In The Shape of Green, the authors propound that the architectural form, shape and aesthetics of the building are a significant part in contributing to well-being. They comment that 'how a building is shaped can have an enormous effect on how it performs, and some sources estimate that up to 90 percent of a product's environmental impact is determined during the early design phases, prior to decisions about technical details. In other words, elementary decisions about shape - the "look and feel" of a design - are essential to sustainability' [4]. The author in The Shape of Green stresses on the sensory aspect of the aesthetics of sustainability. 'Form affects performance, image influences endurance' [4]. This aspect relates directly to the well-being of the users. He continues to say that 'long-term value is impossible without sensory appeal' and 'at every scale of experience, shape is critical to environmental performance and human response' [4]. From this, we can infer that green or sustainable architecture comes from a fusion of function, aesthetics, form, structure and services and is contextual, where each aspect is connected and significant in its impact on its users. A systems and integrated approach are, therefore, deemed essential.

\section{THEORETICAL FRAMEWORK}

\subsection{Impact of vernacular architecture}

Local vernacular architecture is sustainable architecture. It represents solutions based on garnering knowledge of well workable solutions over time into buildings and acts as repository of regional building knowledge based on culture and history. In post-independent India, a modernist-influenced architectural landscape, it has been said that today, 'The built environment in which we live has been shaped by two dominant traditions - a vernacular one which tends to be protective of its inhabitants and that of the Modern Movement which aimed at an "open" architecture of light and space' [5]. However, there is debate on this view as Perera comments 'limitations of modernist architecture in regard to its universal claims and the subsequent need to differentiate designs were recognized by even the modernists themselves' [6]. He continues to say 'it is evident in the much-discussed tropical architecture' [6].

\subsection{Laurie Baker architecture}

Laurie Baker's architecture is an example of architecture that responds to both traditions. It is essentially 'Green' in its concepts and uses strategies derived from a study of local vernacular architecture to suggest new forms and solutions within a largely modernist approach of adherence to function and seeing 'truth in materials'. Bhatia comments 'in the course of 
several discourses of the Mahatma, Baker imbibed the meaning of one of his most persistent messages-that change in post-independent India can be brought about only through education and the revival of the local crafts and cottage industries' [7].

'Laurie Baker's architecture and writings have shown that an understanding of existing vernacular architecture needs to be included in future development through a planned evolution, to design house forms based on real user needs, socio-cultural identities and passive design for climatic comfort, minimising the need for mechanical ventilation, using local materials as low energy resources and building robust houses which can be maintained by communities' [8].

'His architect-builder approach to design and construction show a unique work ethic that has imparted a hand-crafted quality to his buildings. Baker's designs are cost effective and user-oriented and present simple solutions' [9]. 'He spoke of a common sense, context specific, low-waste, resource management approach in all stages of design and construction. He advocated the use of energy efficient material, especially renewable and reusable ones and locally available materials' [7]. In Untold Stories [9], Kannan describes five of Baker's houses. 'The book is primarily photo-documentation of houses supported by drawings and comments made by the users. Laurie Baker was a pacifist and a Quaker who came to India at the end of the Second World War, on his return journey from China to England. He met Mahatma Gandhi and was strongly influenced by his philosophy which corroborated with his Quaker ideals and modernist thinking of simplicity and function. Baker returned to India and worked in Uttar Pradesh near Pithogarh for 16 years building a hospital amongst other projects which brought him in close contact to the local people. These two opportunities were significant in moulding his architectural philosophy' and 'It was in this period that Baker's understanding and appreciation of the skill and wisdom of traditional building crafts matured and stabilised' [10]. Asif Ali comments 'Baker's work is an innovation without imitating the traditional style' [11]. Speaking about the comparison between modern architecture, Baker is said to have commented 'this Himalayan domestic architecture was a perfect example of vernacular architecture-simple, efficient, inexpensive' [10]. It was able to respond to climate and lifestyle, and dealt with hazards. 'For a sustainable development of built environment, minimization of input energy and low energy intensive material is an essential part' [11]. Vernacular buildings across the globe provide instructive examples of sustainable solutions to building problems [12]. 'A number of practitioners are also inspired by building traditions, given that the local vernacular forms have proven to be energy efficient and green, supported by local resources, geography, and climate' [13]. In the recent years, books and articles have been written on the uses of vernacular strategies in modern building especially with respect to climate and passive energy techniques. There is literature that makes reference to early beginnings in 'the 1960s environmental movements' and 'how its critique contributed to the rise of "sustainable development" in the 1980s' [14]. Laurie Baker started using green practices as early as the 1970s. 'Laurie Baker's concepts prompt the resurgence of provincial building practices and the use of local raw material' [15]. In the Centre for Development Studies in Trivandrum in 1977, his signature perforated brick jalli walls is extensively used as a structural solution seen in the reticulated wall and as a ventilation device in the boy's hostel. 'Baker's designs consist of sloping roofs and terracotta Mangalore tile shingles with gables and vents that allow rising hot air to escape with curved walls that enclose more volume at a low material cost' [15].

Baker learnt from Gandhiji to use materials within a 5 mile radius. 'An integrated approach needs to be adopted in designing a building that can strengthen enhanced energy resource efficiency in new construction' [13]. Baker's approach is holistic and follows a 
green integrated approach using sustainable practices as commented by Bhatia in his book Laurie Baker Life and Works [7]. Baker's architecture is not only 'in response to the specific conditions of topography and climate, but with the aim of providing the best possible buildings for the least amount of money' [16]. Steemers comments that 'in simple shallow plan buildings, where most occupants sit close to openable windows, it is found that the occupants are much more tolerant of temperature swings and environmental conditions in general, making much less demand on the mechanical systems' [17]. Baker's houses are not deep plans and all rooms receive direct light and ventilation. 'Reducing energy loads is a main concern for green architecture' [18].

\subsection{Vernacular architecture passive energy solutions and their interpretation in Baker's designs}

With reference to Kerala vernacular architecture, 'The incorporation of different passive cooling techniques is implemented in order to attain comfortable thermal conditions which has always been present in the vernacular architecture for a long time' [19]. Quick heat loss is a problem where insulation can make the indoor temperature higher than the outdoor temperature. 'In Kerala vernacular architecture, the above problem is overcome with the constant air exchange between outdoor and indoor with the help of openings provided on the external wall' [20].

The focus on the paper is to illustrate the way in which Baker has, through innovative design strategies in the architecture of the wall, taken into account the needs of users answering all comfort levels at a reduced level of resources and energy usage. Climate, comfort and energy are considered as basic design parameters in the integrated approach to energy-efficient building advocated by him.

In vernacular structures according to Dili et al., 'The entry to the building is provided from South or East. The spaces that are used during the day time are mostly placed on the North and South sides while those used during the nights are on the West' [20].

Laterite and lime mortar are used in context of their thermal properties. Cooling through ventilation is achieved through 'provision of open gables (mughappu) in the roof and the provision of wooden jalli (azhi) in the external walls at appropriate positions' [20]. The wooden jalli (azhi) in the external walls in appropriate positions helps to draw external air with the effect of courtyards [20].

Baker uses these techniques but substitutes the wooden jalli for a jalli in brickwork. He uses brickwork that is non-plastered and a rat trap bond technique he invented, which reduces cement by $30 \%$. Concrete is used only in the slab where he has reduced the quantity in his invention of the filler slab whereby recyclable tiles and waste material of broken tiles can be used. The entry space is used from its traditional context in his buildings.

\subsection{Green building 'Vitruvius' points of consideration}

At the start of the project, these are 'Record site biodiversity and ecological quality $\bullet$ Analyse site for sunlight, shelter and available shading - Research building type and analyse good practice examples • Consider what is achievable within cost constraints.' And at design level, 'Locate buildings with reference to passive strategies, including solar and daylight access. Optimise proportion and distribution of external envelope openings with heating, cooling and daylighting in mind • Apply appropriate room heights for heating, cooling and 
daylighting design, select materials and construction methods having regard to thermal mass and life cycle issues and specify electrical lighting equipment and controls for lowest consumption' [1].

\subsection{Sustainability and green standards}

'Sustainability is generally defined as a process of satisfying human/societal needs without compromising the needs of future generations' [21]. 'Indian Green Building Council (IGBC) Green Homes is the first rating programme developed in India, exclusively for the residential sector. It is based on accepted energy and environmental principles and strikes a balance between known established practices and emerging concepts' [22].

\section{METHODOLOGY}

Three houses designed and built by Baker during the 1990s will be studied with respect to their facades. All three are located in Trivandrum, Kerala. Houses will be described in context of parameters drawn from green principles reviewed in the theoretical framework and an analysis on the façade of each house in Section 4. In Section 5, feedback from users will be analysed and findings drawn to arrive at conclusions.

\section{DISCUSSION}

Points drawn from collating the above best practice guidelines have been represented in Tables 1-10. The respective points have been addressed to the three houses under consideration and inferences have been given. House 1 corresponds to Mrs Narayanan, House 2 to $\mathrm{Mr}$ George and House 3 to Mrs Padma Subrahmaniam.

\subsection{Climate}

Kerala has a warm, humid climate because of its location. 'Kerala has mainly two seasons, the monsoon season and non-monsoon season, in which winter and summer comes under non-monsoon season' [19]. Thiruvananthapuram is $36 \mathrm{~m}$ above sea level and has a tropical climate. 'Rainfall is significant most months of the year, and the short dry season has little effect. West and north west wind direction 36-37\% of the year and north and northeast 8-12\%' [25]. 'April is the warmest month of the year. The temperature in April averages $26.9{ }^{\circ} \mathrm{C}\left(80.4{ }^{\circ} \mathrm{F}\right)$. August is the coldest month, with temperatures averaging $25.0{ }^{\circ} \mathrm{C}$ $\left(77.0{ }^{\circ} \mathrm{F}\right)^{\prime}[26]$.

\subsection{The façade wall}

The external wall or façade in a conventional building is an expression of the building's character and can be read as text with embedded meanings of status, imagery, socio-cultural aspects and function. 'A facade advertises the interior space behind it, initiates the act of entrance, and prepares visitors for what they will encounter inside. Like a human face, it expresses personal identity and recognizability, and displays a certain inner constitution, at times like a mask, one that - whether playfully or with deceptive intent - endows a building with a changing identity' [23]. In green architecture, the façade is not simply a mask but also a filter that retains and optimises, and reduces and filters to enhance well-being of the users with the lowest environmental impact. It aims 'to encourage the adoption of materials with a 
limited embodied energy, recyclable and with limited impact during production chain, construction phase and end service life' [24].

Baker's approach utilised minimum drawings with the design emanating from frequent visits to site and review of site conditions as commented by Da Cunha and Kuriakose [27] who trained under him and by his client Mrs Narayanan, whose house is being discussed in this paper. Local skilled labour was used with whom he worked closely. Great attention was paid to detail and site context. In this sense, passive design strategies were worked into the design before and during the process of building in a way that the building evolved out of a site-specific and 'green' process.

The three houses to be studied are in proximity to each other in Trivandrum. They were all built in the 1990s. As Baker did not prepare detailed drawings of his projects, all material shown in this paper is through accessible information from the book Untold Stories by Kannan [9], published by Laurie Baker Centre and with kind permission of Mr Anil Kumar of Laurie Baker Centre.

\subsection{Analysis}

For ease of description, Mrs Narayanan's house will be referred to as House 1 (refer to Fig. 1), Mr George's house as House 2 (refer to Fig. 2) and Mrs Padma Subrahmaniam's house as House 3 (refer to Fig. 3).

\subsubsection{Site}

Factors that determined the location of the house in all cases were privacy, climatic factors of achieving light and ventilation and maximising on views. A plot coverage of $30 \%$ was maintained in the smaller plots of House 2 and House 3. In House 1, the site was large and the ratio of plot to footprint in ground floor was 1:44 (refer to Table 1 and Fig. 1). Large areas of open space that are landscaped are used as thermal buffers and as screens for privacy.

\subsubsection{Expression of the house through its façade (physical attributes)}

Mrs Narayanan's house is a one-storey structure where the façade wall is angled and delineated with chinks and curved alcoves. Timber columns, niches and jalli work decorate the faces and express the identity of the owner within the architectural language of Baker. Baker closely worked with the owner to accommodate in the façade-salvaged timber columns (refer to Table 2). The scale is small as the roof dominates and extensively covers window openings that pierce the ground storey wall and project out of the roof.

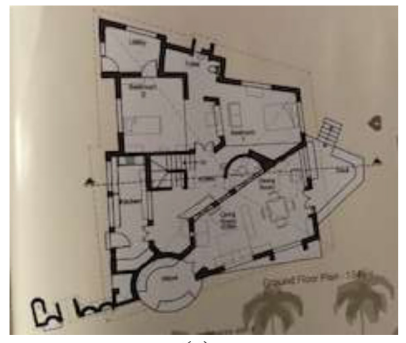

(a)

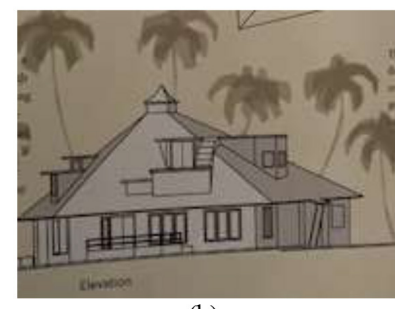

(b)

Figure 1: (a) Plan of House 1 and (b) its elevation [9]. 


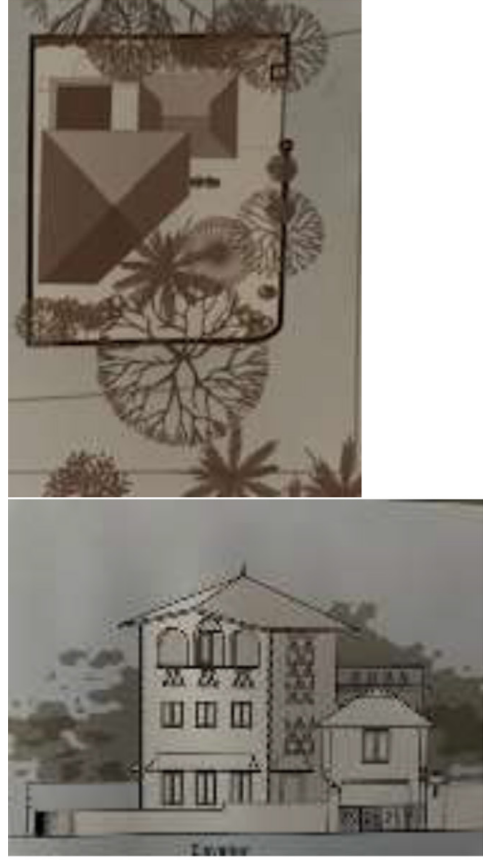

(a)

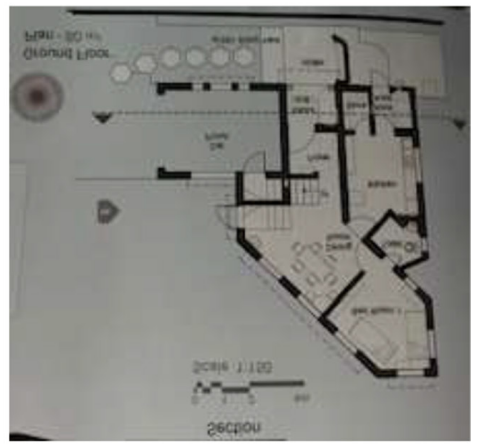

(b)

Figure 2: (a) Site of House 2, (b) plan and (c) elevation [9].

The impression is of a porous structure with a slightly picturesque image created by its juxtaposing geometries. Referring to Fig. 2, Mr George's house retains the quality of the porous and the picturesque façade by its massing of three storeys with an overall pattern of windows and arched openings and with individual patterning seen in the jalli designs, all emanating from functional needs. Mrs Padma Subrahmaniam's house represents a similar character through its faceted form representing many surfaces, all of which are punctured with openings suitably shaded.

Exposed brickwork is the common language in all houses with jalli designs and corner detailing expressing technique and craftsmanship as aesthetic art and expression.

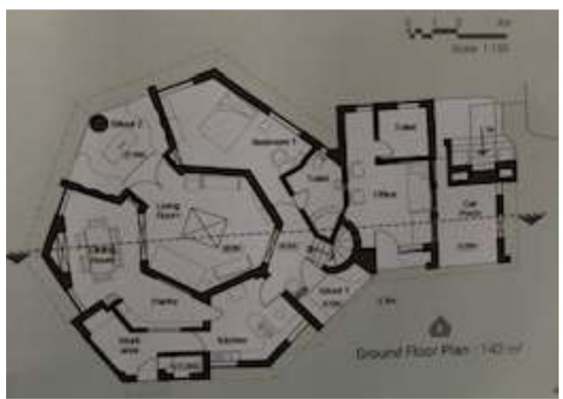

(a)

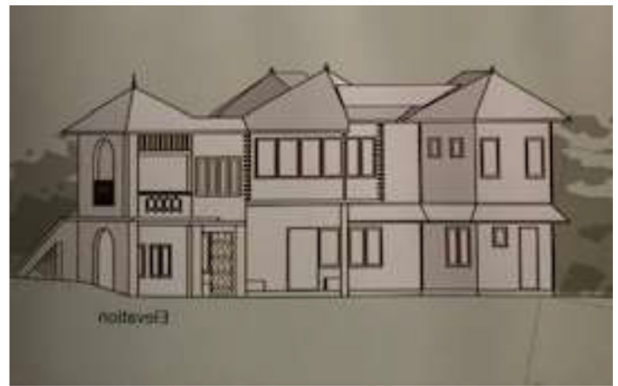

(b)

Figure 3: (a) Plan of House 3 and (b) its elevation [9]. 
Table 1: Site.

\begin{tabular}{|c|c|c|c|}
\hline & House 1 & House 2 & House 3 \\
\hline Site selection & $\begin{array}{l}\text { Site was chosen prior } \\
\text { to selection of architect }\end{array}$ & $\begin{array}{l}\text { Approved site } \\
\text { selection }\end{array}$ & $\begin{array}{l}\text { Approved site } \\
\text { selection }\end{array}$ \\
\hline $\begin{array}{l}\text { Respect the ecological } \\
\text { value of the site }\end{array}$ & $\begin{array}{l}\text { A book was given } \\
\text { to the client by the } \\
\text { architect to increase } \\
\text { vegetation and to grow } \\
\text { plants and trees. }\end{array}$ & $\begin{array}{l}\text { Yes, compact } \\
\text { plan placed at } \\
\text { one corner. }\end{array}$ & Yes \\
\hline Area of house & $171 \mathrm{sq} \mathrm{m}$ & $198 \mathrm{sq} \mathrm{m}$ & $241 \mathrm{sq} \mathrm{m}$ \\
\hline No of bedrooms & 2 & 2 plus studio & 3 \\
\hline Area of footprint & $134 \mathrm{sq} \mathrm{m}$ & $80 \mathrm{sq} \mathrm{m}$ & $142 \mathrm{sq} \mathrm{m}$ \\
\hline Area of plot & $5,900 \mathrm{sq} \mathrm{m}$ & $271 \mathrm{sq} \mathrm{m}$ & $492 \mathrm{sq} \mathrm{m}$ \\
\hline Plot coverage & $2.3 \%$ & $30 \%$ & $29 \%$ \\
\hline No of storeys & 2 & 3 & 2 \\
\hline $\begin{array}{l}\text { Plot area to ground floor } \\
\text { area }\end{array}$ & $1: 44$ & $1: 3.38$ & $1: 3.46$ \\
\hline $\begin{array}{l}\text { Location of house } \\
\text { Context }\end{array}$ & $\begin{array}{l}\text { Set in with a view to } \\
\text { the lake }\end{array}$ & $\begin{array}{l}\text { Set in one corner } \\
\text { with view to golf } \\
\text { course }\end{array}$ & Centrally located \\
\hline $\begin{array}{l}\text { Mitigating ecological } \\
\text { impact }\end{array}$ & Low footprint & Low footprint & Low footprint \\
\hline $\begin{array}{l}\text { Entry } \\
\text { Main rooms located }\end{array}$ & North & South & South \\
\hline Day use & North and south & North and south & North and south \\
\hline Night & East and west & East and west & East and west \\
\hline
\end{tabular}

Table 2: Management.

\begin{tabular}{|c|c|c|c|}
\hline & House 1 & House 2 & House 3 \\
\hline $\begin{array}{l}\text { Responsible construction } \\
\text { practices } \\
\text { Works with labour }\end{array}$ & Yes & Yes & Yes \\
\hline Construction site impacts & Negligible & Negligible & Negligible \\
\hline Stakeholder participation & $\begin{array}{l}\text { Works with user } \\
\text { and each house is } \\
\text { individual }\end{array}$ & $\begin{array}{l}\text { Works with } \\
\text { user and each } \\
\text { house is indi- } \\
\text { vidual }\end{array}$ & $\begin{array}{l}\text { Works with user } \\
\text { and each house is } \\
\text { individual }\end{array}$ \\
\hline
\end{tabular}

\subsubsection{Entry}

In the case of Mrs Narayanan's house, the house was set back deep inside the plot, and Table 1 and Fig. 1 show the significance given to privacy in terms of the location. Mr George's house (Fig. 2) was oriented to a corner and the entry is perpendicular to the road such that the high compound wall of the adjacent golf course can enforce privacy. One enters the rear as the front faces the back garden. In Padma Subrahmaniam's house (refer to Fig. 3), the faceted 
shape of the house allows it to be visible in parts and enforces privacy. Except House 1, which has a north entry, the other two houses have a south-facing entry.

The context of entry has a role on location of fenestration and openings on the façade, which in turn effect thermal comfort. Breeze is largely from the southwest and a south entry facilitates improved comfort. Greenery plays a significant role in bringing down the micro climate in the site, and shielding and shading the house from neighbours and heat. $\mathrm{Mr}$ George's house is compact in shape with the front façade at the rear splayed to face north and green space.

\subsubsection{Room positioning}

In House 1, living and dining overlook two sit outs and large expanse of greenery and the lake view to the south. In House 2 (refer to Fig. 2), the porch faces the road and privacy is ensured to living and dining spaces by virtue of the splay in the plan, which orients the dining room at an angle and overlooking a large open green space. In effect, the façade faces the rear of the plot. The living room is placed on the first floor to afford more light and ventilation. In House 3 (refer to Fig. 3), Padma Subrahmaniam's house, Baker has used rooms to buffer the centrally located living room, which opens up through sit outs on north and south.

\subsubsection{Windows}

Windows are made in timber frames and open into private spaces shielded from neighbours. In Mrs Narayanan's house (refer to Table 3), large windows almost 6 feet in length with low sills feature in living room and bay windows project out in the top floor. While in $\mathrm{Mr}$ George's house, large windows in the living room give extended views of the garden. All three houses feature bay windows. Large windows as in Mr George's house contain fixed glass panels with openable shutters. In all houses, a mixture of sizes is used.

\subsubsection{Verandas spill over spaces and inside/outside connect}

Two sit outs in House 1 visually extend the house into the garden and integrate interior and exterior. The low wall has a built-in seat, which is supported on brick corbelling, a feature in Baker's houses. In House 2, the second-floor veranda offers a view to the golf course. 'There is a feeling of openness here. There is privacy from outside-no one sees us unless they are particularly looking. It is so peaceful' [9]. The veranda has a jalli-patterned parapet wall to increase air movement and has arches to frame openings and support the roof.

\subsubsection{Micro climate}

Adequate trees and landscaping around the building reduce the temperature. Mrs Narayanan comments that Baker did not approve of lawn as a solution for landscape but preferred growing flora natural to the terrain. The ratio of open space to footprint is also favourable in

Table 3: Innovation.

\begin{tabular}{llll}
\hline & House 1 & House 2 & House 3 \\
\hline $\begin{array}{l}\text { New technology, pro- } \\
\text { cess and practices }\end{array}$ & $\begin{array}{l}\text { Innovative use of } \\
\text { recycled windows and } \\
\text { details with respect to } \\
\text { client's needs }\end{array}$ & $\begin{array}{l}\text { Cost budgeting } \\
\text { solutions, wall as } \\
\text { structure and use } \\
\text { of arches }\end{array}$ & $\begin{array}{l}\text { Use of elements } \\
\text { such as windows } \\
\text { to function in dual } \\
\text { roles as shading } \\
\text { device, etc }\end{array}$ \\
\hline
\end{tabular}


Table 4: Micro climate.

\begin{tabular}{llll}
\hline & House 1 & House 2 & House 3 \\
\hline $\begin{array}{l}\text { Creating a } \\
\text { microclimate }\end{array}$ & $\begin{array}{l}\text { Planting of trees, } \\
\text { etc avoiding heat } \\
\text { island effect }\end{array}$ & $\begin{array}{l}\text { Planting of trees, etc } \\
\text { avoiding heat island } \\
\text { effect }\end{array}$ & $\begin{array}{l}\text { Planting of trees, avoiding } \\
\text { heat island effect, etc }\end{array}$ \\
\hline
\end{tabular}

improving the micro climate. It is approximately 1:34 in House 2 and House 3, and much larger in House 1 (refer to Table 4).

\subsubsection{Materials and construction}

Local materials for wall construction were used in all three houses. Exposed brickwork with no plastering on the surface. In House 1, the woodwork is recycled from a demolished house. However, in House 2, the timber used for woodworking was Malaysian timber chosen for its relatively low price (refer to Table 5). A brick column was built out of waste brick (refer to Table 6).

\subsubsection{Lifecycle}

The brickwork has proved to be a durable material. The wall has, according to the owners, required little maintenance, and the brickwork is sound after almost 30 plus year (refer to Table 5).

\subsubsection{Light}

Large windows were positioned at different sill heights and above the lintel in assorted shapes and sizes. Ample light and with a soft quality that does not generate glare as commented by all three owners (refer to Table 7).

Table 5: Materials.

\begin{tabular}{|c|c|c|c|}
\hline & House 1 & House 2 & House 3 \\
\hline Life cycle impacts & $\begin{array}{l}\text { Brick in walls have } \\
\text { needed little mainte- } \\
\text { nance in } 30 \text { years }\end{array}$ & $\begin{array}{l}\text { Brick in walls } \\
\text { have needed little } \\
\text { maintenance in } 30 \\
\text { years }\end{array}$ & $\begin{array}{l}\text { Brick in walls have } \\
\text { needed little mainte- } \\
\text { nance in } 30 \text { years }\end{array}$ \\
\hline $\begin{array}{l}\text { Responsible sourc- } \\
\text { ing of materials }\end{array}$ & $\begin{array}{l}\text { Local materials } \\
\text { - less impact on } \\
\text { environment }\end{array}$ & $\begin{array}{l}\text { Local materials } \\
\text { except budgetary } \\
\text { constraint - use of } \\
\text { Malaysian timber } \\
\text { for windows }\end{array}$ & $\begin{array}{l}\text { Local materials - less } \\
\text { impact on environ- } \\
\text { ment }\end{array}$ \\
\hline $\begin{array}{l}\text { Design for robust- } \\
\text { ness }\end{array}$ & Yes & Yes & Yes \\
\hline Structure & $\begin{array}{l}\text { Brick as loadbear- } \\
\text { ing, arches used } \\
\text { Significant reduction } \\
\text { in use of cement }\end{array}$ & $\begin{array}{l}\text { Brick as loadbear- } \\
\text { ing, arches used } \\
\text { Significant reduc- } \\
\text { tion in use of } \\
\text { cement }\end{array}$ & $\begin{array}{l}\text { Brick as loadbearing, } \\
\text { arches and brick piers } \\
\text { used } \\
\text { Significant reduction } \\
\text { in use of cement }\end{array}$ \\
\hline
\end{tabular}


Table 6: Waste.

\begin{tabular}{llll}
\hline & House 1 & House 2 & House 3 \\
\hline Construction waste management & $\begin{array}{l}\text { A column was built with } \\
\text { left over brick waste. }\end{array}$ & Negligible & Negligible \\
Operational waste & Negligible & Negligible & Negligible \\
\hline
\end{tabular}

Table 7: Visual comfort.

\begin{tabular}{llll}
\hline & House 1 & House 2 & House 3 \\
\hline Daylight & Ample windows & Ample windows & Ample windows \\
& Jalli - scattered light & Jalli - scattered light & Jalli - scattered light \\
Visual & Yes, as in soft light & Yes, as in soft light & Yes, as in soft light \\
comfort & achieved with no & achieved with no glare & achieved with no glare. \\
& glare & & Central living room, how- \\
& & & ever, does require addition- \\
& & & al light on a cloudy day \\
\hline
\end{tabular}

\subsubsection{Ventilation}

Ventilation is provided amply and even when the doors are shut; Baker has provided openings in the brickwork over the doors to facilitate air movement (refer to Table 8).

Table 8: Ventilation.

\begin{tabular}{llll}
\hline & House 1 & House 2 & House 3 \\
\hline $\begin{array}{l}\text { Orientate the build- } \\
\text { ing to optimise on } \\
\text { ventilation }\end{array}$ & $\begin{array}{l}\text { Building is oriented } \\
\text { to open up to north } \\
\text { and south }\end{array}$ & Faces the north & $\begin{array}{l}\text { Faceted facade, } \\
\text { faces the north and } \\
\text { south }\end{array}$ \\
$\begin{array}{l}\text { Harness breeze by } \\
\text { careful location of } \\
\text { openings }\end{array}$ & $\begin{array}{l}\text { Entry in west } \\
\text { Entry }\end{array}$ & $\begin{array}{l}\text { Sit out and entry in } \\
\text { north } \\
\text { On all sides }\end{array}$ & $\begin{array}{l}\text { Ontry in east with } \\
\text { sit out in west and } \\
\text { terrace facing west } \\
\text { on first floor }\end{array}$ \\
$\begin{array}{llll}\text { Sit out } & \text { On all sides }\end{array}$ \\
$\begin{array}{l}\text { Windows } \\
\text { Jalli openings }\end{array}$ & $\begin{array}{l}\text { Above door entry as } \\
\text { jalli opening }\end{array}$ & $\begin{array}{l}\text { In staircase as jalli } \\
\text { opening }\end{array}$ \\
$\begin{array}{l}\text { Above lintel sky- } \\
\text { light openings }\end{array}$ & $\begin{array}{l}\text { For release of warm } \\
\text { air - skylights }\end{array}$ & $\begin{array}{l}\text { For release of warm } \\
\text { air - skylights }\end{array}$ & $\begin{array}{l}\text { For release of } \\
\text { warm air }- \text { sky- } \\
\text { lights }\end{array}$ \\
\hline
\end{tabular}


Table 9: Shading.

\begin{tabular}{llll}
\hline & House 1 & House 2 & House 3 \\
\hline $\begin{array}{l}\text { Orientate the building to allow for natural shading } \\
\text { by trees and vegetation }\end{array}$ & Yes & Yes & Yes \\
Shape of building assists in shading & Yes & Yes & Yes \\
\hline
\end{tabular}

\subsubsection{Shading}

Roof overhangs and sunshades ensure shading to protect glare and rain from entering. Rough texture of the exposed brick and the angles and undulations in the wall outline help with shading (refer to Table 9).

\subsubsection{Wall aesthetics}

In all houses, the overall expression is rustic, natural and organic and does not reveal a strict ordering geometry, but a love of geometry in context of shape and expressed in a love of pattern making seen in the decorative jallis and the patterns they cast by their light and shadows. A tension in design forces is seen by an almost baroque sense of freedom of line and curve seen in the articulation of the wall, in competition with an overall composition of a sense of 'connectedness' to the ground. Sloped roofs reference the vernacular. A sense of play is hinted at in the ensuing assemblage and collage effect of different patterns and forms manifesting the architect's innovativeness (refer to Table 10).

Table 10: Aesthetics.

\begin{tabular}{|c|c|c|c|}
\hline & House 1 & House 2 & House 3 \\
\hline Aesthetic balance & $50 / 50$ & $50 / 50$ & $50 / 50$ \\
\hline $\begin{array}{l}\text { Juxtaposition of geometric } \\
\text { shapes and forms }\end{array}$ & Yes & Yes & Yes \\
\hline Pattern making & $\begin{array}{l}\text { In jallis and brick- } \\
\text { work }\end{array}$ & $\begin{array}{l}\text { In jallis and } \\
\text { brickwork }\end{array}$ & $\begin{array}{l}\text { In jallis and brick- } \\
\text { work }\end{array}$ \\
\hline Truth to materials & $\begin{array}{l}\text { Exposed brick- } \\
\text { work }\end{array}$ & $\begin{array}{l}\text { Exposed brick- } \\
\text { work }\end{array}$ & Exposed brickwork \\
\hline $\begin{array}{l}\text { Sense of informality of } \\
\text { Combination of elements }\end{array}$ & Yes, sense of play & Yes & Yes \\
\hline $\begin{array}{l}\text { Composition allowed } \\
\text { Addition of other elements }\end{array}$ & $\begin{array}{l}\text { Yes, carved } \\
\text { wooden pillars }\end{array}$ & Not applicable & $\begin{array}{l}\text { Yes, a room was } \\
\text { built }\end{array}$ \\
\hline Detailing & $\begin{array}{l}\text { Corbelling and } \\
\text { corner wall joint } \\
\text { articulation }\end{array}$ & $\begin{array}{l}\text { Corbelling and } \\
\text { corner wall joint } \\
\text { articulation }\end{array}$ & $\begin{array}{l}\text { Corbelling and } \\
\text { corner wall joint } \\
\text { articulation }\end{array}$ \\
\hline $\begin{array}{l}\text { Responded aesthetically } \\
\text { to site }\end{array}$ & Yes & Yes & Yes \\
\hline $\begin{array}{l}\text { Labour intensive and craft } \\
\text { oriented }\end{array}$ & Yes & Yes & Yes \\
\hline
\end{tabular}


Table 11: Socio-cultural and functional quality.

\begin{tabular}{|c|c|c|c|}
\hline & House 1 & House 2 & House 3 \\
\hline $\begin{array}{l}\text { Confirm floor to ceiling } \\
\text { heights to maximise daylight } \\
\text { and natural ventilation }\end{array}$ & $\begin{array}{l}\text { Larger volumes to } \\
\text { modulate air flow } \\
\text { in the interior }\end{array}$ & Proportionate & $\begin{array}{l}\text { Proportionate } \\
\text { with skylight to } \\
\text { improve air flow } \\
\text { and release warm }\end{array}$ \\
\hline $\begin{array}{l}\text { Confirm façade proportions, } \\
\text { and provision and design of } \\
\text { external shading if necessary }\end{array}$ & $\begin{array}{l}\text { Facade undula- } \\
\text { tions help struc- } \\
\text { tural stability and } \\
\text { cause shading }\end{array}$ & $\begin{array}{l}\text { Angled rooms. } \\
\text { Least wall length } \\
\text { for area was at- } \\
\text { tempted }\end{array}$ & $\begin{array}{l}\text { air. } \\
\text { Faceted walls of } \\
\text { façade. } \\
\text { Least wall length } \\
\text { for area was at- } \\
\text { tempted }\end{array}$ \\
\hline Quality of outdoor spaces & Verdant & Verdant & Verdant \\
\hline Suitability for conversion & Yes & Yes & $\begin{array}{l}\text { Has converted } \\
\text { porch into a room }\end{array}$ \\
\hline Social integration & $\begin{array}{l}\text { Lifestyle and } \\
\text { needs incorporated }\end{array}$ & $\begin{array}{l}\text { Lifestyle and } \\
\text { needs incorpo- } \\
\text { rated }\end{array}$ & $\begin{array}{l}\text { Lifestyle and } \\
\text { needs incorpo- } \\
\text { rated }\end{array}$ \\
\hline
\end{tabular}

\subsubsection{Well-being and a sense of place}

The connectedness to the environment and visual context to each part of the site enhance a sense of place and well-being made possible through the relationship the external wall makes with the environment and the people of the house through its openings and physical presence and materiality. Interplay of light and shadow by wall and Jallis stimulates interest and evokes a sensory response. Seating by the wall offers an anchor and vantage point from which social interaction can take place integrating with the outside in entry transition spaces such as sit outs. House 3 owner Mrs Padma Subrahmaniam comments 'this was our best discussion and chatting area' [9] (refer to Table 11).

\subsubsection{Vernacular interpretations as energy-saving devices}

In all three houses, jallis and sit outs and the introduction of skylights to release warm air feature as significant contributions derived from the vernacular. 'Rough texture causes self-shading of walls. This is one of the reasons for low temperature in traditional buildings' [28]. The shading provided by rough wall texture is seen in the extensive use of exposed brickwork and brick corbelling.

\section{FINDINGS}

\subsection{Feedback from users}

Feedback from users propose an informal post-occupancy evaluation. Questions related to post-occupancy issues with respect to the exterior wall are tabulated in Table 12 in point form with answers by users. 
Table 12: Feedback from users.

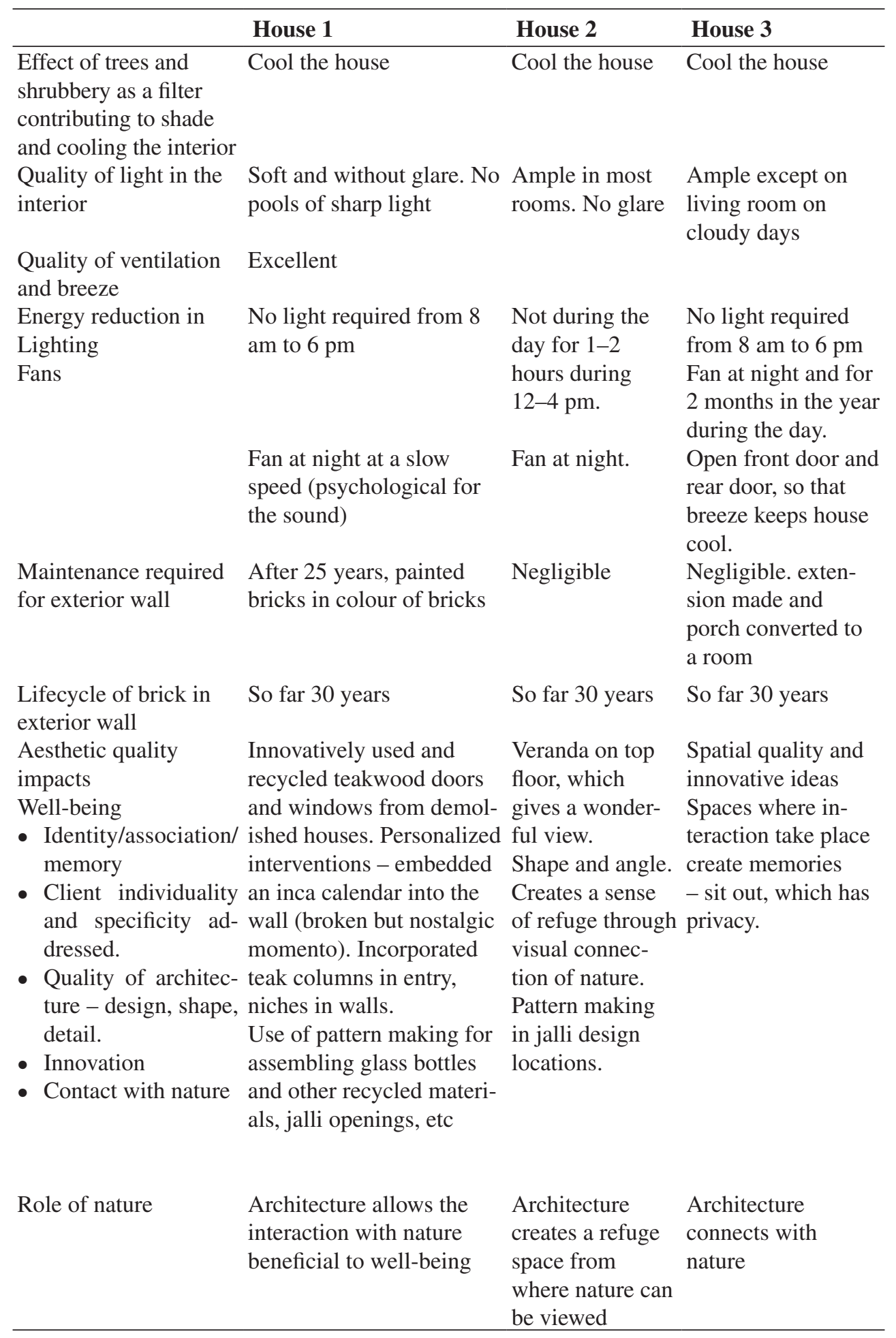




\subsection{Patterns}

Inferring from the analysis, one can suggest a system of designing the façade wall based on strategies employed by reading from the patterns used. Pattern definitions are taken from The Coding Manual for Qualitative Researchers [29].

1. Similarity (things happen the same way)

- Micro climate. Trees and vegetation are used as a thermal and acoustic barrier around the house.

- Entry is always climatically controlled through a buffer space, usually a sit-out.

- Jallis that provide permanent small openings are utilised to maintain air circulation in the interior.

- Wall outline is articulated to move in and out and undulate for reasons pertaining to structural stability, shading and ensuring privacy.

- Faceted wall surfaces are used to generate more opportunities for windows at minimum wall length.

- Structure is factored in such that openings use brick flat lintels and arched openings without need for concrete structural members.

- Standardised window schedule of joinery is not adhered to and the façade presents windows of a range of sizes and shapes.

- External openings connect internally to give cross ventilation in the interior.

- Shading is addressed by greenery and in the texture of exposed brickwork, provision of overhangs, sunshades and walls.

- Exposed brickwork in bond or using rat-trap bond.

2. Difference (they happen in predictably different ways)

- Baker's language of jalli, brick corbelling, arches and the manipulation of the external wall into chinks, curves and angles. A different aesthetic solution is reached in each house, but the architectural grammar is the same.

- Openings are always provided above lintels in different forms as jalli openings or fanshaped openings or skylight openings to release warm air to cool the interior.

- The sit out is a predictable space but changes in shape in each house, based on site specificity and context.

3. Correspondence (they happen in relation to other activities or events)

- Location of house is always in relation to topography and the plan emerges from user needs and site characteristics of climate and terrain.

4. Sequence (they happen in a certain order)

- Privacy is always respected, and in all houses, there is a sequence from semi-public space or the transition space of the sit out to the private space of the interior, which is a cultural expression and is based on lifestyle.

\section{CONCLUSIONS}

From the findings, it is clear that Laurie Baker's architecture of the three houses is green in design and works favourably with respect to user satisfaction. Porosity in the wall has been the principal strategy to enforce maximum air movement. Numerous passive energy-based architectural strategies for façade design enumerated can be incorporated to promulgate a green design approach for houses in India, thereby establishing a relevance to the study. The extensive use of nature to improve the environment climatically and socially suggest the intersection of biophilia and eco-architecture seen here. Further sustainable thinking is assured 
in the manner in which vernacular knowledge systems as heritage have been transferred into contemporary working systems continuing tradition and celebrating the craftsman.

\section{ACKNOWLEDGEMENTS}

I would like to thank architect Sajan for his support and putting me in touch with the three houseowners and for his suggestion to study on Baker's use of pattern in his building vocabulary. Architect Sajan was trained under Laurie Baker and continues his work under the aegis of Costford. I would like to thank the three houseowners - Mrs Narayanan, Mr George and Mrs Subrahmaniam - for their support and giving me their valuable time. I would like to thank Mr Anil Kumar of Laurie Baker Centre for giving me permission to use images from the book Untold Stories published by Laurie Baker Centre.

\section{REFERENCES}

[1] Brophy, V. \& Owen Lewis, J., A Green Vitruvius, Principle and Practice of Sustainable Architectural Design, Earthscan, UK, 2011.

[2] Eghbali, Z. \& Didari, A., Building design and construction using concept of sustainability. Proceedings of the 3rd International Conference on Civil, Structural and Transportation Engineering (ICCSTE'18), Niagara Falls, Canada, Paper No. 135, June 10-12, 2018.

[3] Ragheba, A. \& El-Shimyb, H., Green architecture: a concept of sustainability. Procedia - Social and Behavioral Sciences, 216, pp. 778-787, 2016. https://doi.org/10.1016/j. sbspro.2015.12.075

[4] Hosey, L., The Shape of Green, Aesthetics, Ecology and Design, Island Press, USA, p. 24, 2012.

[5] Thomas, R. \& Garnham, T., The Environments of Architecture: Environmental Design in Context, Taylor and Francis, 2007.

[6] Perera, N., Critical vernacularism: A locally produced global difference. Journal of Architectural Education, 63(2), pp. 76-77, 2010. https://doi.org/10.1111/j.1531314x.2010.01064.x

[7] Bhatia, G., Laurie Baker Life and Works, Penguin: New Delhi, 1991.

[8] Mishra, M., Laurie Baker's contribution to the continuation of vernacular architecture in India. International Journal of Environmental Studies, 73(4), pp. 631-650, 2016. https://doi.org/10.1080/00207233.2016.1179011

[9] Kannan, K.P., Untold Stories, Laurie Baker Centre, India, 2021.

[10] Burte, H., The Gandhi of spatial delight. Economic and Political Weekly, 42(18), pp. 1606-1609, 2007.

[11] Asif, A., Sustainability in vernacular architecture: Laurie Baker and Hassan Fathy's approach. Anthropological Bulletin, 5(2), pp. 43-46, 2015.

[12] Rashid, M. \& Ara, D.R., Modernity in tradition: Reflections on building design and technology in the Asian vernacular. Frontiers of Architectural Research, 4(1), pp. 46-55, 2015. https://doi.org/10.1016/j.foar.2014.11.001

[13] Arya, S., Rena \& Kumar, S., The concept of energy-efficient residential block design. Current Developments in Biotechnology and Bioengineering, Elsevier, pp. 185-210, 2019.

[14] Purvis, B., Mao, Y. \& Robinson, D., Three pillars of sustainability: in search of conceptual origins. Sustainability Science, 14, pp. 681-695, 2019. https://doi.org/10.1007/ s11625-018-0627-5 
[15] Jain, A.K., Humble, humane and harmonious houses of Laurie Baker. International Journal of Environmental Studies, 67(5), pp. 781-794, 2010. https://doi.org/10.1080/0 0207233.2010.517297

[16] Mostafavi, M., Enriching identities-the architecture of Laurie Baker. $a+u$ Architecture and Urbanism Magazine, 2000.

[17] Baker, N. \& Steemers, K., Energy and Environment in Architecture: A Technical Design Guide, E\&FN Spon, UK, 2003.

[18] Haggag, A., The use of green walls in sustainable urban context: With reference to Dubai, UAE. WIT Transactions on Ecology and the Environment, 128, pp. 261-270, 2010.

[19] George, A.T. \& Dash, S.P., Exploring feasibility of passive cooling techniques in residential buildings in Kerala. International Journal of Innovative Technology and Exploring Engineering (IJITEE), 9(2), December 2019.

[20] Dili, A.S, Naseer, M.A. \& Varghese Zacharia, T., Passive environment control system of Kerala vernacular residential architecture for a comfortable indoor environment: A qualitative and quantitative analyses. Energy and Buildings, 42(6), pp. 917-927, 2010. https://doi.org/10.1016/j.enbuild.2010.01.002

[21] McClure, W.R. \& Bartuska, T.J., eds., The Built Environment: A Collaborative Inquiry into Design and Planning, John Wiley: Hoboken, N.J., p. 39, 2007.

[22] https://igbc.in/igbc/ (Accessed 28th June 2021)

[23] Tigges, F. \& Janson, A., The Vocabulary of Spatial Situations: Fundamental Concepts of Architecture, Birkhäuser: Berlin, Boston, 2014.

[24] Boeri, A., Gianfrate, V. \& Longo, D., Green buildings and design for adaptation: Strategies for renovation of the built environment. International Journal of Energy Production \& Management, 1(2), pp. 172-191, 2016. https://doi.org/10.2495/eq-v1-n2-172-191

[25] https://www.weatheronline.in (Accessed 28th June 2021)

[26] https://en.climate-data.org/asia/india/kerala/thiruvananthapuram-2783/ (Accessed 28th June 2021)

[27] https://www.arvindguptatoys.com > baker-japan (Accessed 8th July 2021)

[28] Akella, V.L., Thermal performance of traditional and modern buildings in Kerala, South India. Sustainable Building Conference, Tokyo, 27-29 September 2005.

[29] Saldana, J., The Coding Manual for Qualitative Researchers, Sage, U.K., 2016. 